\title{
Perilaku Ekonomi Masyarakat Desa
}

\section{Kasus Kredit Pedesaan Indonesia}

Oleh : Hudlyanto

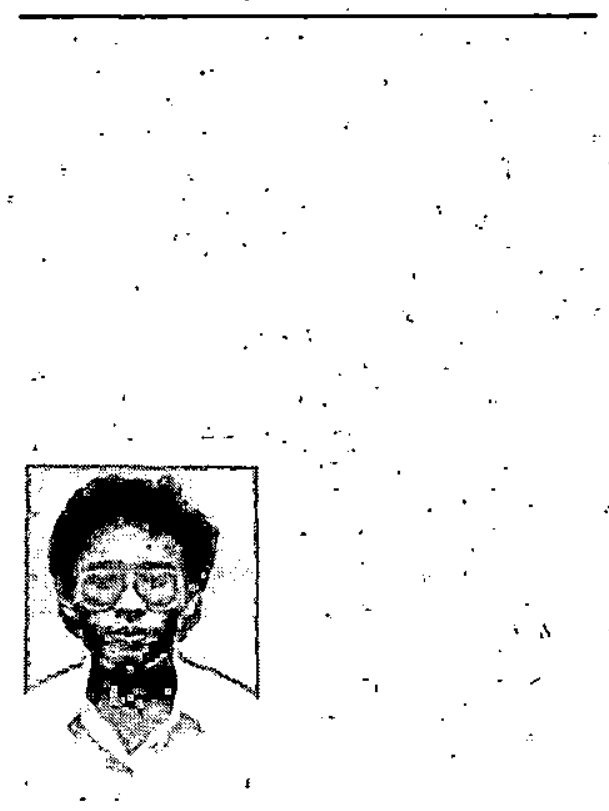

Hudiyanto, adalah dosen pada Eàkultas Ekonomi Universitas Muhammadiyah Yogyakarta, lahir pada 25 Nopember 1960 di Yogyakarta.

Menamatkan studl, di Fakultas -Ekonomi UGM-tahun 1985. Aktif melakukan penelitian sebagai staf pada Pusat Penelitian Pembangunan Pedesaan dan Kawasan (P3PK) UGM.
Dalam membicarakan suatu program permbangunan masyarakat desa, satu hal yang tidak bisa dilupakan dan diabaikan adalah dalam membagi kelompok masyarákat menjadi kelompók masyarakat kaya dan kelompok masyarakat miskin di daerah pedesaan, karena diantara keduanya mempunyai karakteristik yang berbeda. Pembedaan seperti ini sama sekali bukan untuk mempertentangkan di antara kedua kelompok itu, tetapi sekedar untuk membedakannya. Pembedaan tersebut menjadi penting karena dalam kehidupan sehari-hari didapatkan bahwa perilaku orang kaya berbeda dengan perilaku orang miskin

Pembedaan tersebut perlu dilakukan oleh karena selama ini selalu saja ada perbedaan persepsi orang terhadap masing-masing kelompok tersebut. Ada anggapan dan apriori bahwa "mengurus" orang miskin jauh lebih susah dibandingkan dengan "mengurus" orang kaya. Orang kaya selalu diidentikkan dengan sikap-sikapnya yang rasional, yang berorientasi untuk mencapai kemajuan dan pengembangan diri dan yang oleh karenanya mudah untuk menerima inovasi yang diperkenalkan oleh pemerintah atau pihak luar. Sementara itu ada anggapan bahwa berhubungan dengan kelompok masyarakat 
miskin amat susah. Mereka "susah" untuk diajak maju berkembang, karena jalan fikirannya yang "tidak" rasional.

Akibatnya mereka amat sulit menerima inovasi yang diperkenalkan untuk meningkat taraf hidupnya. Tuduhan kepada masyarkat desa sebagai tidak mau maju, tidak rasional dan bersikap hidup statis mempunyai sejarah ketika seorang ekonom yang juga birokrat Belanda di Indonesia yang bernama Boeke mengungkapkan tesisnya tentang orang Jawa-miskin. Dalam penelitiannya dia menemukan keterbelakangan masyarakat miskin Jawa disebabkan oleh karena sikapnya yang statis dalam kehidupan sehari-harinya. Dari pengalamannya di Jawa itulah Boeke menjadi penemu teori baru yang menjadi topik pembicaraan bagi ekonom di negaranegara sedang berkembang. Teori baru ini disebut sebagai teori Dualisme, yang membagi masyarakat ekonomi menjadi dua : masyarakat maju dan masyarakat tradisional. Masyarakat ekonomi maju terdiri dari orang-orang yang bergaya barat, yang menggunakan sikap rasional dalam menghadapi masalah-masalah ekonominya, yang menggunakan ekonomi uang dalam kehidupan sehariharinya. Karena itu Boeke menyebutnya sebagai perekonomian modern dan pelakunya cukup dinamis. Di lain pihak dalam perekonomian yang sama ada kelompok masyarakat yang mempunyai sistem ekonomi tersendiri yang masih bersifat tradisional, menggunakan sistem barter, tidak menggunakan sikap rasional dalam melakukan àktifitas ekonomi. Dalam perekonomian tradisional ini pelaku ekonominya mempunyai tingkat kehidupan yang rendah, yang, kata Boeke, disebabkan oleh sikapnya yang statis. Mereka itulah masyarakat miskin, terutama, di pedesaan.

"Tuduhan" Boeke bahwa orang Jawa miskin karena sifatnya yang statis disangkal oleh Clifford Geertz yang menyatakan bahwa mereka menjadi statis karena kemiskinannya yang sudah lama ditanggungnya, yang hal itu disebabkan oleh penjajahan Belanda. Karena miskin, maka mereka selalu berhatihati, dalam menghadapi setiap perubahan yang diprogramkan pemerintah. Sebab setiap bentuk perubahan mesti mengandung resiko, di mana, karena kemiskinannya, masyarakat desa akan enggan menanggungnya. James C Scott melukiskan keadaan ini sebagai berikut :

Mereka bagaikan sedang berdiri di dalam air, di mana ketinggian air sampai di leher. Dia tidak beranjak, karena begitu beranjak, akan timbulah gelombang air yang akan menenggelamkan dirinya. (Scott, 1981).

Gambaran Scott begitu gamblang untuk menggambarkan kehidupan masyarakat desa, untuk menggambarkan mengapa masyarakat miskin pedesaan sangat hati-hati untuk bergerak. Mereka menjadi statis dalam menerima teknologi karena kondisi yang tidak memungkinkan untuk dinamis. Sikap hatihati ("statis") seringkali ditunjukkan oleh mereka ketika pemerintah atau lembaga yang bergerak di pedesaan menawarkan perbaikan hidup. Beberapa contoh bisa dikemukakan. Pengenalan teknologi tepat. guna dalam pemanenan berupa penggunaan sabit menggantikan ani-ani ditentang oleh masyarakat meskipun penggunaan teknologi baru tersebut lebih efisien dan memberikan hasil yang lebih tinggi kepada petani. Penentangan tehadap teknologi baru tersebut nampak "tidak 
rasional", tetapi sebenarnya menjadi rasional kalau diselami jalan fikiran mereka. Dengan teknologi model lama berupa sistem "ani-ani" ada rasionalitas dilihat dari jalan fikiran petani. Dengan sistem ani-ani, ada pembagian kekayaan kepada semua orang karena orang yang mau disebabkan untuk ikut serta dalam proses pemanenan. Dengan demikian, maka "penentangan" masyarakat desa terhadap teknologi baru yang diperkenalkan didasarkan atas pertimbangan: "dari pada tetangga hidup melarat, lebih baik hidup tidak efisien dengan teknologi lama, tetapi semua orang bisa menikmati".

"Ketidak-rasionalan" jalan fikiran masyarakat desa dalam melakukan aktifitas ekonomi bisa dilihat pula dalam penampilan mereka dalam menghadapi kredit yang ditawarkan kepada mereka. 'Dibandingkan dengan tanggapannya terhadap lembaga-lembaga kredit informal (baik yang resmi maupun tidak resmi), tanggapan masyarakat desa terhadap lembaga-lembaga kredit resmi pemerintah nampak kurang menonjol (Edy Suandi Hamid \& Hudiyanto 1987). Hal ini disebabkan oleh penampilan lembaga resmi yang "setengah-setengah" dalam menerobos pasar masyarakat miskin yang masih relatif tradisional.

\section{Ketergantungan pada lembaga informal.}

Ekonomi dualitas masih banyak yang menggugat keberadaannya sebab adanya dualisme dalam perekonomian dianggap bersifat sementara saja. Namun demikian, lepas dari ada tidaknya Ekonomi dualitas dalam perekonomian di dalam kebijaksanaan pemerintah baik masa kolonial maupun masa pemerintah
RI, dualisme itu "diakui" keberadaannya. Karena pemerintah Indonesia mengakui adanya dualisme, maka dalam pelaksanaan pembangunan pemerintah "sedikit banyak" memisahkan sektor Modern dengan sektor Tradisional, suatu kebijaksanaan "diskriminatif" yang pada penjajahan dianggap sebagai pembenaran atas kelestarian penjajahan di Indonesia.

"Kebijaksanaan yang "dualistis" ini terlihat dalam pembedaan antara kelompok masyarakat ekonomi lemah dengan kelompok masyarakat ekonomi kuat, dan oleh karenanya juga pembedaan status ekonomi kuat dan ekonomi lemah. Dalam pelaksanaan kebijaksanaan akhirnya muncul pembedaan perlakuan terhadap perlakuan/kebijaksanaan, tentu saja didasarkan karena satu kebijaksanaan tunggal tidak akan bisa secara efektif dilaksanakan di Indonesia.

Adanya pembedaan perlakuan di Indonesia tersebut antara lain bisa dilihat dengan jelas dalam dunia perkreditan. Selain didirikan bank-bank resmi yang beroperasi secara perbankan, pemerintah mendirikan bank, yang beroperasi secara tidak konvensional bank. Dalam dunia perbankan pemerintah mengundangkan UU perbankan No. 14/1976 yang mengatur praktek perbankan secara keseluruhan di Indonesia. Namun demikian pemerintah merasa yakni bahwa undang-undang tersebut tidak akan bisa berjalan secara menyeluruh untuk semua lapisan masyarakat itu, kemudian pemerintah membentuk lembaga-lembaga memberi kredit yang tidak diatur secara perbankan untuk melayani kelompok "di luar garis" itu.

Dengan saluran praktek perbankan di 
luar kerangka resmi undang-undang inilah maka pemerintah bisa menyalurkan dananya kepada kelompok yang dianggap masih tradisional. Penyaluran uang itu antara lain nampak lewat berbagai macam kredit kecil dan gurem kepada masyarakat lewat lembaga setengahsetengah (dalam artian setengah resmi/ perbankan). Lewat saluran-saluran itulah pemerintah mempunyai pretensi untuk membebaskan masyarakat lemah ekonomi itu dari jeratan lembaga-lembaga informal dan illegal yang berkembang dimasyarakat, seperti renternir, bank-bank dan pelepas uang yang lain. Dari uraian di atas, nampak bahwa pemerintah sudah sejak lama ingin menerobos dualisme finansial yang ada yaitu memasuki daerah tradisional dengan lembaga formal/semi formal pemerintah. Lembaga yang dibentuk pemerintah ini sudah dimulai sejak abad 19 ketika diperkenalkan tiga macam sistem kredit masing-masing pegadaian, lumbung desa dan bank desa.

Tetapi dari penelitian mikro yang dilakukan di daerah. Klaten ditemukan bahwa dalam satu desa terdapat beberapa lembaga perkreditan dimana lembaga perkreditan informal dan ilegal menempati peran yang amat penting seperti terlihat dalam tabel berikut.

Tabel.

Jumlah Anggota Lembaga Perkreditán di Desa Wiro, Kabupaten Klaten

\begin{tabular}{lccl}
\hline & $\begin{array}{c}\text { Kepala } \\
\text { Keluarga }\end{array}$ & $\begin{array}{c}\text { Tahun } \\
\text { mulai }\end{array}$ & Tingkat \\
\hline Koperasi Kredit & 800 & 1960 -an & Kalurahan \\
Arisan & 50 & 1985 & 3 Pedukuhan \\
Y I S & 120 & 1982 & 3 Pedukuhan \\
B K D & 40 & 1960 -an & Kalurahan \\
\hline Jumlah KK & 1.010 & & \\
\hline
\end{tabular}

Sumber : P3PK-UGM, 1987.
Dari Tabel di atas nampak bahwa lembaga perkreditan resmi seperti Badan Kredit Desa (BKD) mempunyai anggota yang jauh lebih kecil apabila dibandingkan dengan lembaga perkreditan informal seperti Koperasi Kredit. Demikian juga dengan volume usahanya, lembaga kredit informal di pedesaan mempunyai volume usaha yang jauh lebih besar dari pada volume usaha lembaga kredit resmi pedesaan. Kalau diingat bahwa tingkat bunga yang dikenakan oleh lembaga informal cukup tinggi, ahli ekonomi tentu "tidak habis tahu", mengapa masyarakt desa masih tetap berhubungan. Dalam penelitiannya di Temanggung ditemukan bahwa tingkat bunga yang tinggi tidak menjadi masalah bagi masyarakat desa.

Dengan bunga secara "nglimolasi" nasabah yang mempunyai pinjaman Rp 435.000,- mengembalikan pada musim panen dengan jumlah $\mathrm{Rp} 652.500,-$. Bunga tersebut sudah relatif tinggi. Namun apabila sedang untung atau hasil tembakaunya baik dan laku mahal, petani memberikan lebih dari itu. Seorang pelepas uang mengatakan bahwa nasabahnya yang diberi pinjaman $\mathrm{Rp} 500.000$,- mengembalikan sejumlah Rp $1.000 .000,-$. Sebaliknya, kalau hasil tembakau dan pemasaran sedang tidak baik, pelepas uang memberikan korting. Ada seorang petani yang pinjam uang kepada pelepas uang sebesar $\mathrm{Rp} 350.000,00$. Menurut ketentuan dia harus mengembalikan sebesar Rp 525.000,00, tetapi oleh juragan hanya diterima $R p 500.000,00$, uang Rp 25.000,00 dikembalikan pada nasabah, (P3PK-UGM, 1987).

Nampak bahwa petani mau membayar bunga dalam tingkat yang cukup tinggi. Bahkan kalau keadaan memungkinkan mereka akan membayar lebih dari kewajiban sebenarnya. Perilaku 
"aneh" mereka dalam aktifitas perkreditan tersebut tentu mempunyai sebabsebab yang bisa dinalar. Mereka berperilaku seperti itu oleh karena lembaga formal yang menawarkan kredit dengan tingkat bunga yang murah tidak mampu menjangkau mereka. Ada hal-hal yang merupakan kelebihan dari lembaga kredit informal/legal yang tidak dipunyai oleh lembaga kredit formal sekalipun lembaga tersebut sudah dimodifikasi untuk keperluan masyarakat miskin di pedesaan. Hubungan "kekeluargaan" yang akrab antara nasabah dengan pelepas uang merupakan alasan utama.

\section{Ikatan Kekeluargaan}

Kantor lembaga informal hanya digunakan sebagai pos bagi pegawainya untuk melayani anggota dari rumah ke rumah. Dengan pos itulah mereka akan datang ke rumah-rumah dengan berbagai pendekatan kepada masyarakat. Hubungan antara lembaga dengan nasabah dengan demikian akan menjadi intim. Lebih-lebih lagi pada rentenir, hubungan dekat ini akan sangat dirasakan. Rentenir di Jepara pada masa lalu, misalnya, sering memberikan beras, gula dan kebutuhan lain apabila masa peceklik datang; "Kedermawaan" rentenir dalam hal ini jelas tidak akan pernah dilupakan oleh nasabah.

Hal ini berbeda dengan lembaga kredit resmi di mana kalau seseorang ingin berhubungan/meminjam uang di lembaga itu, mereka harus pergi ke kantor pada jam-jam yang sudah ditentukan. Memang hal ini tidak banyak menimbulkan masalah sejauh pengambilan kredit tersebut memang akan digunakan untuk tujuan-tujuan produktif sebagaimana diinginkan oleh pemerintah. Akan tetapi untuk warga yang memerlukan uang untuk tujuan konsumtif, hal ini akan menimbulkan masalah. Sebab ada perasaan, dengan pergi $\cdot k e$ kantor kalurahan atau bank mereka memarkan diri bahwa "saya tidak bisa memenuhi kebutuhạn hidup sèhari-hari". Pemenuhan kebutuhan hidup adalah masalah yang amat peribadi karena hal itu menyangkut kehormatan dan harga diri keluarga. Bisa difahami kalau akhirnya masyarakat yang tidak mempunyai usaha pokok enggan untuk berhubungan dengan lembaga formal. Dalam hal sifat "pribadi" tentang hutang bagi kelompok miskin ini digambarkan oleh Boeke :

Pegadaian tidak ingin mengetahui apapun tentang keadaan si peminjam; benarbenar pasif, menunggunya di belakang dinding bertirai besi dari rumah gadai, bahkan tidak mencoba mengadakan penyidikan terhadap peminjam, tetapi mempersilakan menghilang dalam gelap. Bagi peminjam rumah gadai memberi kesempatan untuk mengambil jumlah kecil tanpa mengalami pemeriksaan sebelumnya, dan ini berlangsung setiap saat. Bahwa bunganya tinggi tidak merugikannya, karena ia terbiasa dengan itu dan menganggap serasi ...... (Boeke, 1983).

Kalau dalam hal hutang yang merupakan masalah pribadi, lembaga informal "tidak peduli" dan "menutup mata", demikian pula halnya perhațian mereka terhadap pelayanan.

Pada lembaga kredit resmi nasabah datang ke kantor untuk mengembalikan angsurannya pada saat kantornya dibuka. Hanya kalau terjadi tunggakan, maka pihak lembaga tersebut yang dalam hal mengadakan penagihan langsung ke rumah nasabah. Dalam hal ini 
timbul kembali kesan resmi sebagaimana diungkapkan dalam bagian terdahulu. Kedatangan tugas ke rumbah nasabah selalu berarti "akan menagih" pada saat mereka tidak mempunyai uang; sebab adanya tunggakan itu sendiri sudah berarti nasabah sedang tidak mempunyai uang. Dalam hal inilah barangkali terdapat ketidakadilan dalam kebijaksanaannya. Ketika nasabah ingin meminjam mereka harus datang ke kantor; namun ketika justru mereka sedang memerlukan uang, petugas datang untuk meminta angsurannya. "Apakah Bank sudah tidak percaya pada nasabah? Kalau tidak, alangkah malangnya menjadi orang yang tidak dipercaya bahwa ia memang tidak mempunyai uang". Kalau bank percaya, mengapa mesti menagih? Bukanlah ia sedang tidak ada uang? Lantas bagaimana mengembalikannya? Pertanyaanpertanyaan di atas kiranya akan terjadi pada diri nasabah, yang dalam hal ini akan menyangkut kembali pada sifat hubungan antara lembaga dengan nasabah. Hal seperti tersebut di atas tidak terjadi pada lembaga informal. Kedatangan petugas ke rumah penduduk tidak selalu untuk menagih. Kedatangannya adalah kedatangan rutin. Pada saat nasabah ingin mendapatkan uang untuk memenuhi kebutuhan hidupnya, dengan senang hati petugas akan datang membawakan uang langsung ke rumah. Sedangkan kedatangan berikutnya untuk menagih memang sudah menjadi persetujuan, sehingga tidak menjadi beban. Kalau suatu ketika ia tidak mampu membayar angsuran, petugas akan menawarkan jasa baiknya memberikan pinjaman kembali, kalau memang melihat ada jaminan yang bisa dilirik rumah itu. Dengan demikian nasabah selalu merasa masih dipercaya oleh petugas, yang merupakan faktor penting dalam kehidupan orang miskin. Kedatangan petugas tidak selalu dihindari karena membawa dua kemungkinan yaitu penagihan dan pemberian pinjaman baru. Hanya pada saat yang memang sudah begitu kritis di mana rasabah sudah amat lama menumpuk hutang, maka nasabah menjadi kuatir terjadinya penyitaan. Di lain pihak dalam hal ini rentenir atau lembaga itu akan menjadi keras dalam bertindak, yaitu pengambilan barang-barang yang ada di rumah nasabah.

\section{DAFTAR PUSTAKA}

Alexander, Jennifer, Pasar, Pasaran, Traders and Trading in Rural Java, Disertasi doktor Sydney University, 1984.

Boeke, JH, Prakapiralisme di Asia, Sinar Harapan Jakarta, 1983.

Edy Suandi Hamid dan Hudiyanto, Keragaman dan Kemandirian Kredit Pedesaan, prasaran pada Rapat Kerja Badan Kredit Kecamatan Jawa Tengah, 1987.

Mubyarto, Politik Pertanian dan Pembangunan Pedesaan Sinar Harapan, Jakarta, 1983.

Mubyarto dan Edy Suandi Hamid, Kredit Pedesaan, BPFE UGM, 1984.

Scott, James C, Moral Ekonomi Petani. LP3ES, Jakarta, 1981.

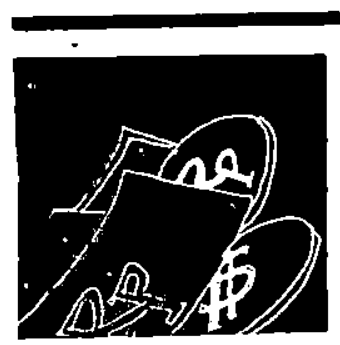

